\title{
A Lesson from the South for Fiscal Policy in the US and Other Advanced Countries
}

\section{Citation}

Frankel, Jeffrey A. 2011. A Lesson from the South for Fiscal Policy in the US and Other Advanced Countries. Comparative Economic Studies 53(3): 407-430.

\section{Published Version}

http://dx.doi.org/10.1057/ces.2011.7

\section{Permanent link}

http://nrs.harvard.edu/urn-3:HUL.InstRepos:8705907

\section{Terms of Use}

This article was downloaded from Harvard University's DASH repository, and is made available under the terms and conditions applicable to Other Posted Material, as set forth at http:// nrs.harvard.edu/urn-3:HUL.InstRepos:dash.current.terms-of-use\#LAA

\section{Share Your Story}

The Harvard community has made this article openly available.

Please share how this access benefits you. Submit a story.

Accessibility 


\title{
Symposium Article
}

\section{A Lesson from the South for Fiscal Policy in the US and Other Advanced Countries}

\section{JEFFREY FRANKEL}

Harvard University, 79 JFK Street, Cambridge, MA 02138, USA.

\begin{abstract}
American fiscal policy has been procyclical: Washington wasted the expansion period 2001-2007 by running budget deficits, but by 2011 had come to feel constrained by inherited debt to withdraw fiscal stimulus. Chile has achieved countercyclical fiscal policy - saving in booms and easing in recession - during the same decade that rich countries forgot how to do so. Chile has a rule that targets a structural budget balance. But rules are not credible by themselves. In Europe and the United States, official forecasts are overly optimistic in booms; so revenue is spent rather than saved. Chile avoids such wishful thinking by having independent panels of experts decide what is structural and what is cyclical.
\end{abstract}

Comparative Economic Studies (2011) 53, 407-430. doi:10.1057/ces.2011.7

Keywords: budget rules, Chile, countercyclical, forecast, structural budget, procyclical

JEL Classifications: E62, F41, H50, O54

\section{INTRODUCTION}

Two decades ago, many people had drawn a lesson from the 1980s: Japan's variant of capitalism was the best model. Other countries around the world should and would follow it. Japan's admired institutions included relationship banking, keiretsu, bonus compensation for workers, lifetime employment, consensus building, strategic trade policy, administrative guidance, pro-saving policies, and corporate goals of maximizing companies' industrial capacity or market share. These features were viewed as elements of Japanese economic success that were potentially worthy of emulation. The Japanese model quickly lost its luster in the 1990s, however, when the stock market and real estate 
market crashed, followed by many years of severe stagnation in the real economy. ${ }^{1}$

A decade ago, many thought that the lesson of the 1990s had been that the United States' variant of capitalism was the best model, and that other countries should and would follow. The touted institutions included armslength banking, competition for corporate control, Anglo-American securities markets, reliance on accounting firms and rating agencies, derivatives, bonus-compensation for executives, an adversarial legal system, deregulation, pro-consumer credit policies, and corporate goals of maximizing companies' profits or share price. These features were viewed as elements of US economic success and potentially worthy of emulation. The American model quickly lost its attractiveness in the 2000s, however, when the stock market and real estate market crashed. Poor economic performance left per capita income and median household income below their levels of 2000 even before the severe US-originated recession of 2008-2009. ${ }^{2}$

Where should countries look now, for models of economic success to emulate?

Perhaps they should look to the periphery of the world economy. Some smaller and less-rich countries have experimented with policies and institutions that could usefully be adopted by others. Singapore achieved rich country status with a unique development strategy. Among its many innovations was a paternalistic approach to saving. Costa Rica in Central America and Mauritius in Africa are each conspicuous performance standouts in their respective regions. Among many other decisions that worked out well, both countries have foregone a standing army. The result in both cases has been histories with no coups and with financial savings that could be used for education and other good things. Slovakia and Estonia in Central/ Eastern Europe have simplified their tax systems by means of a flat tax. ${ }^{3}$

Some of the lessons from emerging market countries can be useful for the big advanced countries. Two illustrations from microeconomics: First, Singapore pioneered the use of the price mechanism to reduce traffic congestion

\footnotetext{
${ }^{1}$ The so-called revisionists, led by Johnson (1982), ridiculed economists' beliefs in free trade and in the proposition that there could be such a thing as too much investment. The literature began with Vogel (1979), a book that was ahead of its time, and ended with Fingleton (1995), which was behind its time. Frankel (1993) surveyed economists' research on the Japanese financial system as of the end of the 1980s.

${ }^{2}$ Frankel (2001) gave the author's views on the US capitalist model and claims of a 'New Economy' as of the end of the 1990s.

${ }^{3}$ Examples of influential innovations from small advanced periphery countries: Inflation Targeting in New Zealand and FDI-friendly tax policy in Ireland. I have pondered the success of Mauritius in Frankel (2010a).
} 
in its urban center. London emulated Singapore when it successfully adopted congestion pricing in 2003; other big cities should do the same. Second, Mexico pioneered Conditional Cash Transfers (CCT). CCT programs, which make poverty benefits contingent on children's school attendance, have been emulated in many countries, and embraced even in New York City. ${ }^{4}$

Some emerging market and developing countries also have lessons for the United States in areas of macroeconomics, specifically regarding the cyclicality of fiscal policy. To state the message of this paper most succinctly, over the last decade countries from Chile to China learned how to run properly countercyclical fiscal policy: taking advantage of boom periods such as 2003-2008 to achieve high national savings, and in particular to run budget surpluses, which then allows some fiscal ease in response to downturns such as 2008-2009. During this same period, advanced countries such as the United States and United Kingdom forgot how to run countercyclical fiscal policy. Perhaps the 'leaders' could look to the 'followers' for some tips on how to get back on track.

\section{WHAT DOES IT MEAN TO DRAW LESSONS FROM THE PERIPHERY?}

Before turning to specifics, let us elaborate on the larger theme that advanced economies could learn some things from developing countries. This line of argument is not meant as an attack on Western values or modes of thought. It is not a paean to Confucian values or native folk remedies in the Andes or Africa. In my view, when Americans lectured others on the virtues of electoral democracy, the rule of law, and market-based economics, they were right. Where they were wrong was the arrogance of the lectures, most especially the failure to see that their own country needed to be on the receiving end just as much as developing countries. ${ }^{5}$

In some cases, American or Western institutions were successfully transplanted to other countries in the past, and now need to be re-imported. An analogy. In the latter part of the 19th century the vineyards of France and other parts of Europe were destroyed by the microscopic aphid Phylloxera vastatrix. Eventually a desperate last resort was tried: grafting susceptible

\footnotetext{
${ }^{4}$ On Conditional Cash Transfer programs, see Rawlings and Rubio (2005) and Fernald et al. (2008). Outside of the economic area as well, the United States could perhaps usefully emulate some institutions from southern neighbors. Mexico has constitutional provisions for the resolution of disputed results in presidential elections without relying on rulings made by appointees of the party leaders themselves; Henríquez (2006).

${ }^{5}$ The proposition that fears regarding managerial incentives and crony capitalism were relevant not just to the financial sector in developing countries but to the United States as well was put forward before the global financial crisis by Rajan (2005) and after the crisis by Johnson (2009).
} 
European vines onto resistant American root stock, which of course had originally been imported from Europe. Purist French vintners initially disdained what they considered a plan to compromise the refined tastes of their grape varieties. But it saved the European vineyards, and did not impair the quality of the wine. The New World had come to the rescue of the Old.

Countries that are small, or far-away, or newly independent, or that are just emerging from a devastating war, are often more free to experiment, than is the United States or other large established countries. Not all the experiments will succeed. But some will. The results may include some useful lessons for others, including for the big guys.

This paper examines the problem of how to make fiscal policy countercyclical. Fiscal policy in the United States, United Kingdom and other advanced countries became less countercyclical after 2001, as governments wasted the opportunity of the 2002-2007 expansion period by running large budget deficits. Meanwhile fiscal policy in Chile became more countercyclical - saving in the boom and easing in the 2008-2009 recession - during the same decade that rich countries forgot how to do it. It has achieved countercyclical fiscal policy by means of some institutions that could usefully be adopted by other countries.

Chile has a rule that targets a structural budget deficit of zero. But rules are not enough in themselves, as the failures of Europe's Stability and Growth Pact (SGP) illustrate. In both Europe and United States, budget forecasts that are systematically overly optimistic are an important part of the problem. Chile's key innovation was to vest responsibility for estimating the long-run trends in budget determinants in panels of independent experts. Other countries might usefully follow Chile's lead, and develop independent institutions that would determine whether a given year's deficit is structural or temporary. The alternative is that politicians, inclined to wishful thinking, forecast that booms will continue indefinitely, with the result that revenue is spent rather than saved.

The paper begins with a discussion of fiscal policy in the United States and other advanced countries. It then turns to the poor performance of institutional structures that are supposed to keep fiscal policy under control. The core of the paper is the lesson from the periphery - Chile's institutional structure.

\section{THE US DEBATE OVER FISCAL POLICY}

The issue at the top of the policy agenda in the United States and United Kingdom now is fiscal policy. Whether American fiscal policy gets back on track will certainly be an important determinant of the country's economic performance in years to come. 
The public discussion is typically framed as if it is a battle between conservatives who philosophically believe in strong budgets and small government, and liberals who do not. In my view this is not the right way to characterize the debate. Let us waive the commonly made point that small government is classically supposed to be the aim of 'liberals', in the 19th century definition, not 'conservatives', and vice versa. My point is very different: those who call themselves conservatives in practice tend to adopt policies that are the opposite of fiscal conservatism. ${ }^{6}$

In the first place, the right goal should be budgets that allow surpluses in booms and deficits in recession. In the second place, the correlation between how loudly an American politician proclaims a belief in fiscal conservatism and how likely he or she is to take corresponding policy steps is not positive.

I can offer three pieces of evidence to bolster the proposition that politicians who describe themselves as fiscal conservatives in rhetoric do the opposite in practice:

(i) The pattern of states whose Senators win pork barrel projects and other federal spending in their home states: 'Red states' tend on average to take home significantly more federal dollars than 'blue states'. Figure 1 shows the correlation between the tendency to vote Republican, shown on the vertical axis, and the state's ranking in the federal dollars sweepstakes shown on the horizontal axis, with the winners to the right. ${ }^{7}$

(ii) The pattern of spending under Republican presidents. When Ronald Reagan, George H.W. Bush, and George W. Bush, entered the White House, not only did budget deficits rise sharply, but the rate of growth of federal spending rose sharply each time as well, as Figure 2 shows. $^{8}$

(iii) The voting pattern among the 258 members of Congress who signed an unconditional pledge in 2004 not to raise taxes: They voted for greater increases in spending than those who did not sign the pledge (Gale and Kelly, 2004).

${ }^{6}$ I would prefer to call their policies 'illiberal' to clarify that their policies are neither liberal in the 19th century sense nor conservative in the modern sense. This claim applies not just to their fiscal policies, but also in other economic matters such as monetary policy and trade policy as well (Frankel, 2003). The same is true with respect to social policy and foreign policy: modern-day American conservatives in practice favor government intervention and radical departures from past practice.

${ }^{7}$ New Jersey is the state that takes the least money home in the rankings, New Mexico the most.

${ }^{8}$ The correlation between budget deficits and spending is positive $(0.86)$. The data reject the Starve the Beast Hypothesis (the claim that tax-cut-induced budget deficits such as those of the 1980s and 2000s put downward pressure on spending). The data instead support the Shared Sacrifice hypothesis (budget deficits can be eliminated under a regime that constrains both on the tax and spending sides, as in the 1990s). 
412

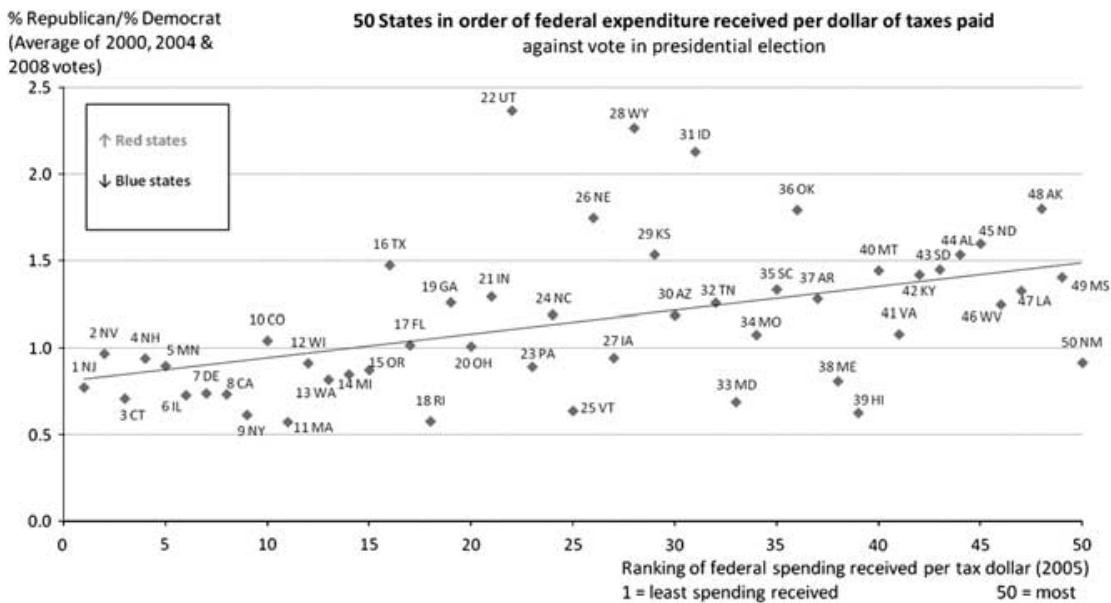

Figure 1: States ranked by federal spending received per tax dollar paid in 2005 versus party vote ratio in recent elections

Data sources: The Tax Foundation and Atlas of US Presidential Elections
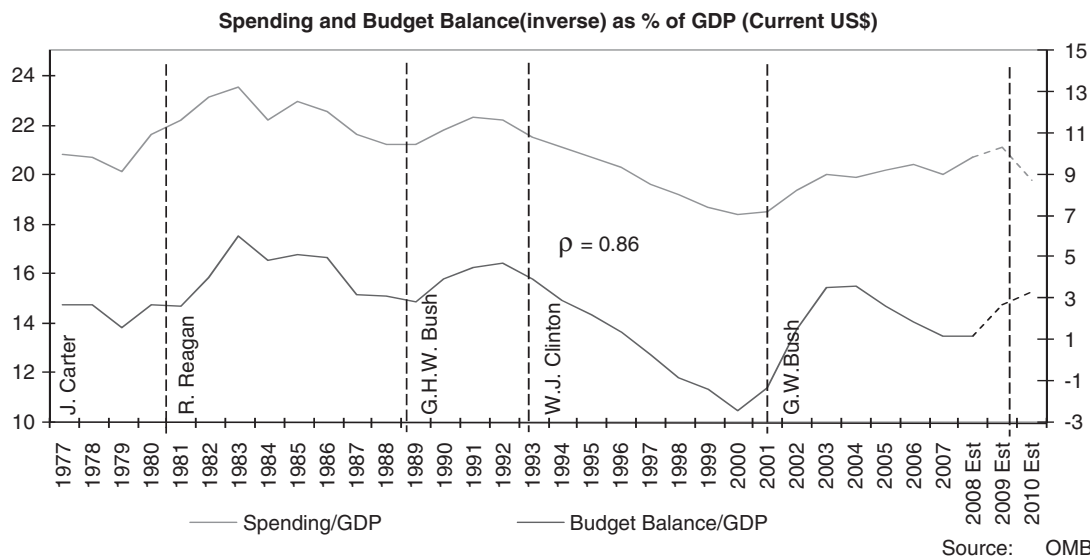

Figure 2: The Shared Sacrifice approach (1990s) succeeded in eliminating budget deficits, but the Starve the Beast approach failed (1980s) and (2000s)

Note: Spending/GDP (upper line) corresponds to scale on left; budget balance/GDP (lower line) corresponds to scale on right.

Source: Frankel (2008)

How are leaders who seek to convince others that they are fiscal conservatives - and probably themselves as well - able to enact tax and spending policies that produce large budget deficits? They do so by means of overly optimistic predictions. Often they make overly optimistic assumptions 


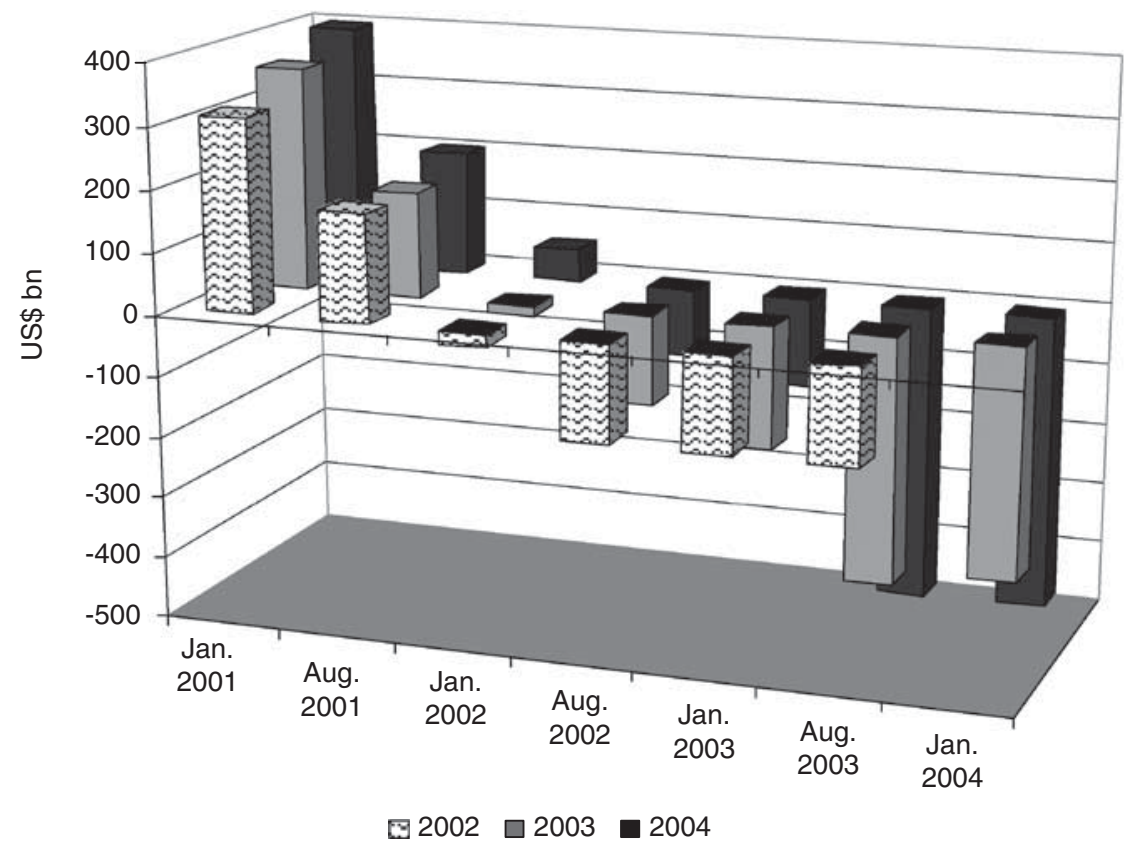

Figure 3: Official US forecasts for 2002, 2003, and 2004 budget surpluses, as revised every 6 months Source: US Office of Management and Budget

about the economic growth rate and other baseline macroeconomic variables. ${ }^{9}$ They also often make overly optimistic assumptions about the boost to growth rates and tax revenues that their policies will yield. Finally, they sometimes deliberately manipulate the timing of legislation so as to misrepresent their plans.

For example, when the Bush administration took office in January 2001, it forecast that the budget surplus it inherited would not only continue but would rise in the future, and would cumulate to \$5 trillion over the coming decade in round numbers. As the actual budget numbers came in, it was forced to revise downward its near-term forecasts every six months, as Figure 3 shows. Even after a recession began in March 2001, the Administration continued to forecast surpluses. Even after the actual balance turned negative in 2002, it predicted that the deficits would soon disappear and turn back into rising surpluses. Throughout President Bush's eight years in office, the official forecasts never stopped showing surpluses after 2011.

${ }^{9}$ This stratagem in the Reagan White House was anthropomorphized under the name Ms. Rosy Scenario. Stockman (1986) and Feldstein (1994, pp. 50, 53). 
414

How were officials able to make forecasts that departed so far from subsequent reality? In three sorts of ways. The first comes in the form of baseline macroeconomic assumptions. Making overly optimistic forecasts of GDP is of course an old trick. A more subtle component of the over-optimistic forecasts of 2001 (small, but revealing): An incoming political appointee at the Office of Management and Budget decided to raise an obscure parameter estimate, the share of labor income in GDP, from the existing technocratic professional estimate. Because labor income is taxed at higher rates than capital income, the change had the effect of artificially raising the forecast for future tax revenue.

More importantly, Bush Administration officials argued publically that their tax cuts were consistent with fiscal discipline by appealing to two fanciful theories: the Laffer Proposition, which says that cuts in tax rates will pay for themselves via higher economic activity, and the Starve the Beast Hypothesis, which says that tax cuts will increase the budget deficit and put downward pressure on federal spending. It is insufficiently remarked that the two propositions are inconsistent with each other: reductions in tax rates can't increase tax revenues and reduce tax revenues at the same time. But being mutually exclusive does not prevent them both from being wrong.

The Laffer Proposition, while theoretically possible under certain conditions, does not apply to the US income tax rate: a cut in those rates reduces revenue, precisely as common sense would indicate. This was the outcome of the Bush tax cuts of 2001-2003, as well as a similar big experiment earlier: the Reagan tax cuts of 1981-1983. Both episodes contributed to record US budget deficits. Rejection of the Laffer Proposition is also the conclusion of more systematic scholarly studies, which rely on more than two data points and try to control for other factors that may be changing at the same time. Getting more major data points requires going further back in history, or including the experience of other countries, or both. ${ }^{10}$ Finally, a heavy majority of professional economists reject the Proposition, including such illustrious economic advisers to Presidents Reagan and Bush II as Martin Feldstein, Glenn Hubbard, and Greg Mankiw. So thorough is the discrediting of the Laffer Hypothesis, that some deny that these two presidents or their top officials could have ever believed such a thing. But abundant quotes suggest that they did. ${ }^{11}$

The Starve the Beast Hypothesis claims that politicians cannot spend money that they don't have. In theory, Congressmen are supposedly inhibited

${ }^{10}$ Goolsbee (1999) analyzes six different U.S. tax changes since 1922. Trabandt and Uhlig (2010) use international evidence to examine the shape of the Laffer curve. Heijman and van Ophem (2005) try also to account for rising tax rates driving economic activities 'underground'.

${ }^{11}$ Further evidence and references on the Laffer Proposition are given in Frankel (2008). 
from increasing spending by constituents' fears that the resulting deficits will mean higher taxes for their grandchildren. The theory fails on both conceptual grounds and empirical grounds. Conceptually, one should begin by asking: what is the alternative fiscal regime to which Starve the Beast is being compared? The natural alternative is the regime that was in place during the 1990s, which I call Shared Sacrifice. During that time, any congressman wishing to increase spending had to show how he or she would raise taxes to pay for it. Logically, a Congressman contemplating a new spending program to benefit some favored supporters will be more inhibited by fears of other constituents complaining about an immediate tax increase (under the regime of Shared Sacrifice) than by fears of constituents complaining that budget deficits might mean higher taxes many years into the future (under Starve the Beast). Sure enough, the Shared Sacrifice approach of the 1990s succeeded in eliminating budget deficits, and did so to a substantial degree by cutting the growth of spending. Compare this outcome to the sharp increases in spending that took place when President Reagan took office, when the first President Bush took office, and when the second President Bush took office (Figure 2). ${ }^{12}$

As with the Laffer Hypothesis, more systematic econometric analysis confirms the rejection of the Starve the Beast Hypothesis. This is the finding of unbiased researchers, whether they are true libertarians (traditional fiscal conservatives) who would prefer to shrink government spending, such as William Niskanen (2002, 2004, 2006), President of the Cato Institute and formerly Member of Ronald Reagan's Council of Economic Advisers or others who might be characterized as of a more liberal bent politically (Gale and Orszag, 2004; and Romer and Romer, 2007).

Overoptimistic macroeconomic assumptions worked in the context of OMB forecasts, and the Laffer and Starve the Beast Hypotheses each gained some traction in the court of public opinion. But to get optimistic fiscal forecasts out of the Congressional Budget Office some more extreme tricks were required, as the independent agency declined to succumb to the Laffer

\footnotetext{
${ }^{12}$ Evidence and references on the Starve the Beast Hypothesis are given in Frankel (2008). The periods of the Starve the Beast regime versus the Shared Sacrifice regime do not correspond perfectly to the periods of Republican versus Democratic presidents, respectively. They correspond better to decades. The first two years of George H.W. Bush's presidency, 1989-1990, were a continuation of Reagan's policies fiscally (the infamous 'no new taxes' pledge). But the first President Bush deserves credit for reversing course in 1990 and negotiating with congressional Democrats the beginning of the Shared Sacrifice regime (including spending caps and the Pay As You Go rules, which were not allowed to lapse until 2001). Conversely, the first two years of Barack Obama's presidency, 2009-2010, were arguably a continuation of the second Bush's fiscal policies (eg, congressional Republicans insisted that all the Bush tax cuts be extended past their 2010 sunset dates).
} 
Proposition, even when headed by a Republican and even when responding to congressional demands that it consider 'dynamic scoring' of tax cuts. ${ }^{13}$

To understand the tricks, begin with the requirement that CBO's baseline forecasts must take their tax and spending assumptions from current law. The Bush Administration exploited this by excising from current law expensive policies that they had every intention of pursuing in the future, often explicitly so. Four examples: the continuation of wars in Afghanistan and Iraq (which were always paid for with 'supplemental' budget requests when the time came, as if they were an unpredictable surprise); annual revocation of purported cuts in payments to doctors that would have driven them out of Medicare if ever allowed to go into effect; annual patches for the Alternative Minimum Tax (which otherwise threatened to expose millions of middle class families to taxes that had never been intended to apply to them); and the intended extension in 2011 of the income tax cuts and estate tax abolition that were legislated in 2001 and 2003 with a phony sunset provision for 2010. All four are examples of expensive policy measures that the Administration fully intended would take place, but that they excluded from legislation so that the official forecasts would misleadingly appear to show smaller deficits and a return to surplus after 2010.

Unrealistic macroeconomic assumptions, fanciful behavioral theories, and legislation that deliberately misrepresents policy plans were all crude ways to get overly optimistic forecasts. But they were not too crude to fool much of the public. Politicians were able to continue posing as fiscal conservatives while enacting tax and spending policies that implied everwidening budget deficits.

Let us summarize the conclusion of the section. The fiscal mess that the United States finds itself in is to some extent attributable to a pattern in recent decades of overly optimistic budget forecasts by government officials. To justify running large budget deficits, even in periods of strong income, they have often unrealistically forecast that the budget deficits will go away in the future. But how is it done in other parts of the world?

\section{A HISTORIC SHIFT IN FISCAL POLICIES AMONG SOME COUNTRIES IN THE SOUTH}

In the past, a heavy majority of developing countries showed a pattern of fiscal policy that was procyclical or - to use a blunter word -

${ }^{13}$ Under Director Douglas Holtz-Eakin, the CBO in 2003 estimated dynamic scoring, but did not find that tax cuts came anywhere near paying for themselves. For details see Frankel (2008, pp. 12-14). 


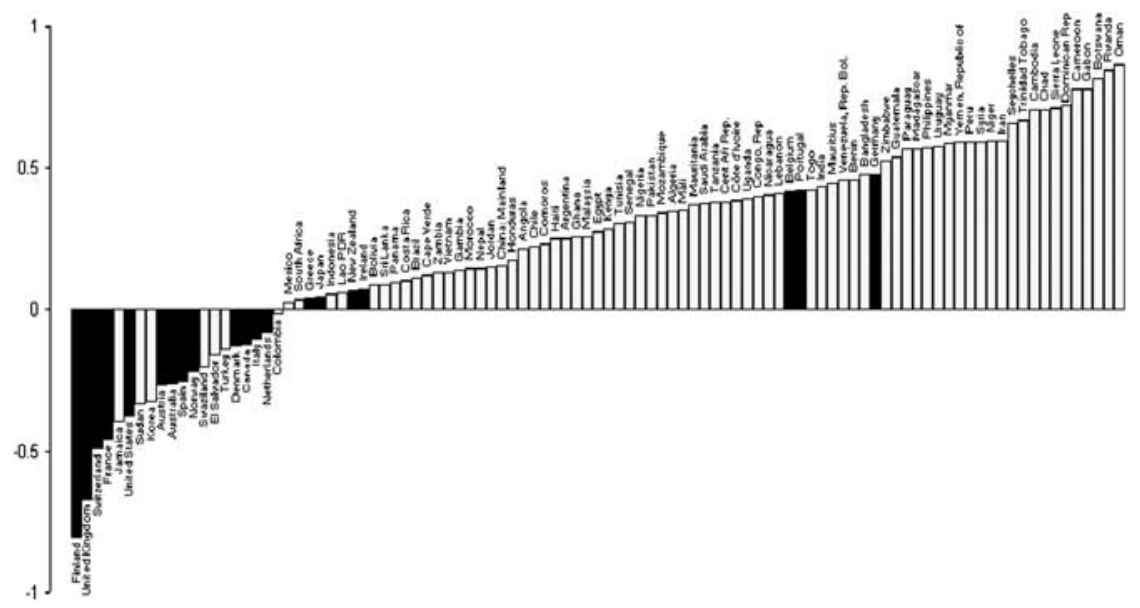

Figure 4: Cyclical correlations between government spending and GDP through 2003

Notes: Dark bars are OECD countries and light ones are non-OECD countries. The cyclical components of both variables were estimated using the Hodrick-Prescott Filter. Real government expenditure is defined as Central Government expenditure deflated by the GDP deflator. A positive correlation indicates procyclical fiscal policy.

Data Source: World Economic Outlook, IMF

Source: Kaminsky et al (2005)

destabilizing. ${ }^{14}$ This was especially true of countries that exported oil, minerals, and agricultural commodities, and particularly countries in Latin America (Gavin and Perotti, 1997; Calderón and Schmidt-Hebbel, 2003; Perry 2003). When world commodity markets boomed and governments should have saved the higher tax revenue, they would instead spend more, sometimes because they mistakenly thought that the boom would last indefinitely. When commodity prices turned back down, the country would be forced to cut spending, thereby exacerbating the downturn.

Kaminsky, Reinhart and Vegh (2005) studied procyclicality for 104 countries over the period 1960-2003. Figure 4, taken from their study, shows for each country the correlation between real government spending and output, both of them cyclically adjusted. Almost every developing country, represented by the light bars, shows a positive correlation, approaching +1 in the case of Oman. This indicates procyclical fiscal policy. Almost every advanced country, represented by the black bars, shows a negative correlation, approaching -1 in the case of Finland. This indicates countercyclical

${ }^{14}$ Procyclical fiscal policy among developing countries has been studied by Tornell and Lane (1999), Kaminsky, Reinhart and Vegh (2005), Talvi and Vegh (2005), Alesina et al. (2008), Mendoza and Oviedo (2006), Ilzetski and Vegh (2008) and Medas and Zakharova (2009). 
fiscal policy. During this period, 1960-2003, the United States and UK show up with negative correlation coefficients that place them among the halfdozen most countercyclical countries.

Over the last decade - and perhaps in reaction to the emerging market crises of the late 1990s - some emerging market countries have moved in the direction of countercyclical or stabilizing fiscal policies. They took advantage of the boom years 2003-2007 to run primary budget surpluses. They reduced their debts, in many cases, to levels lower than the United States and other OECD countries. By 2007, on the eve of the global financial crisis, Latin America and the Caribbean had reduced its debt to $33 \%$ of GDP, as compared to $63 \%$ in the United States. Debt levels among the top 20 rich countries (debt/ GDP ratios around $80 \%$ ) are now twice those of the top 20 emerging markets. Some emerging markets - pronounced 'debt intolerant' not long ago - have earned credit ratings higher than some so-called advanced countries. Korea now has a better credit rating that Portugal. Not only Chile, but also Malaysia, Mexico, Poland and South Africa, now have higher credit ratings than Greece or Iceland. China by 2011 had achieved a credit rating as strong as Japan's.

A stronger fiscal position is one of the reasons that countries such as China could afford to undertake large and sustained fiscal stimulus in response to the 2008-2009 global recession. Other big emerging markets such as Brazil and Indonesia also found themselves freed of the need to cut spending in a recession, and were better able to sail through than the industrialized countries. The United States and United Kingdom, by contrast, had wasted the preceding expansion running budget deficits, and hence by 2010 had come to feel heavily constrained by their debts. As of the date of writing, fiscal consolidation is the political priority in both countries, notwithstanding that output is still well below most measures of potential output.

\section{WHAT SORT OF INSTITUTIONS CAN INSULATE GOVERNMENTS AGAINST POLITICAL PRESSURES TO OVERSPEND IN BOOMS?}

The advice to save in a boom is standard. One would like to be able to do more than cite historical examples of governments that have had the courage to take away the fiscal punch bowl. One would like an example of an innovation designed to deliver countercyclical fiscal policy, an institution that might serve as a template for other countries, a model that can help even in times and places where the political forces to follow procyclical fiscal policy would otherwise be too strong to resist.

The institutions that first come to mind are budget rules, such as the SGP that supposedly constrains fiscal policy among euro members or the Balanced 
Budget Amendment which has periodically been debated in the United States. But the SGP and other such rules have failed miserably, as the sovereign debt troubles in Greece and others on the European periphery had made clear for all to see by 2010. At no point have the SGP's limits on budget deficits and debt levels been credible.

The problems with a simple deficit ceiling rule such as the SGP are well known. If governments are not allowed to run larger budget deficits in recessions than in other times, the recessions will be exacerbated. Indeed, the damage in that circumstance is sufficiently great that it is not politically credible that the country will stick with the rule in the first place. ${ }^{15}$

The alternative is a structural budget rule, one that requires the government to balance the budget on a cyclically adjusted basis. The rule dictates that in a boom spending can be increased, or taxes cut, only to the extent that the growth and therefore surging revenues are deemed permanent. To the extent that the boom is temporary, the revenue should be saved via budget surpluses. This requires forecasts of the short-term and long-term paths of key economic variables. When the economy is expanding, the computation of the structural budget requires an estimate of the extent to which the boom is permanent or temporary. When the economy is in recession, the computation requires an estimate of whether it will recover quickly.

A problem with most budget rules is that such estimation is made by government agencies that are subject to the usual pressures of the political process. Given the genuine uncertainty that surrounds any such estimates, the political pressures need not necessarily be intense for the result to be overly optimistic forecasts of economic growth and revenues. Those forecasts in turn are an excuse for over-spending in the boom.

Research has found econometric support for a series of eight hypotheses regarding forecasts by the official agencies that have responsibility for formulating the budget. The statistical evidence suggests that the overly optimistic US budget forecasts of 2001-2008 were not an isolated episode, but were rather part of a larger historical pattern. Taken together, these seven hypotheses suggest that countries could make their fiscal policies more countercyclical if they adopted institutional arrangements to protect budget forecasting from political pressures, arrangements such as those adopted by Chile over the past decade. ${ }^{16}$

(1) Official forecasts of budgets and GDP are overly optimistic on average. For the United States, McNees (1995) and Auerbach (1994) found an optimistic

\footnotetext{
${ }^{15}$ For this reason, stricter rules in some cases are less credible. Neut and Velasco (2003).

${ }^{16}$ Frankel (2011) gives further details on the empirical results reported here, the Chilean system, and the literature.
} 
Frankel

420

Table 1: GDP growth error in official forecast, in 33 countries: (a) effect of GDP gap; (b) effect of absolute GDP gap

\begin{tabular}{lccc}
\hline Variables & $(1)$ & $(2)$ & $(3)$ \\
& One year ahead & Two years ahead & Three years ahead \\
\hline (a) & & & $0.660^{* * *}$ \\
GDPa & $0.204^{* * *}$ & $0.497^{* * *}$ & $(0.153)$ \\
Constant & $(0.033)$ & $(0.078)$ & $1.438^{* * *}$ \\
& $0.265^{* * *}$ & $0.799^{* * *}$ & $(0.210)$ \\
Observations & $(0.091)$ & $(0.130)$ & 175 \\
$R^{2}$ & 368 & 282 & 0.303 \\
RMSE & 0.138 & 0.298 & 3.397 \\
& 2.234 & 2.945 & $0.743^{* * *}$ \\
(b) & & & $(0.233)$ \\
Absolute GDP & & & 0.133 \\
Constant & 0.133 & $0.531^{* * *}$ & $(0.491)$ \\
Observations & $(0.106)$ & $(0.114)$ & 175 \\
$R^{2}$ & -0.019 & -0.255 & 0.220 \\
RMSE & $(0.242)$ & $(0.314)$ & 3.594 \\
\hline
\end{tabular}

${ }^{a}$ GDP is measured as deviation from a quadratic trend, and lagged so that it lines up with the year in which the forecast was made.

${ }^{\mathrm{b}}$ Absolute GDP is the absolute value of the GDP deviation.

${ }^{*} p<0.1,{ }^{* *} p<0.05,{ }^{* *} p<0.01$. Robust standard errors in parentheses, clustered by country.

bias in official forecasts of growth. Auerbach (1999) found a tendency for OMB to overestimate revenues during the period 1986-1993, but found a tendency to underestimate revenues during the period 1993-1999 (during the Clinton Administration). Frendreis and Tatalovich (2000) and McNab et al. (2007) also find bias in OMB forecasts, which they attribute to political influences. Forni and Momigliano (2004) find optimism bias among OECD countries more generally. Ashiya (2007) finds that official Japanese growth forecasts at a 16-month horizon are biased upwards. Jonung and Larch (2006) find a clear tendency for EU governments, when making budget plans, to overestimate the economic growth rate. Most of these authors argue that the systematic over-optimism in ex ante forecasts translates directly into larger ex post deficits.

(2) The bias toward over-optimism is greater in booms, and increases with the horizon of the forecasts. Apparently government policymakers are subject to wishful thinking, so that each boom is judged to be permanent. ${ }^{17}$ Table $1 \mathrm{a}$ and $\mathrm{b}$

${ }^{17}$ This pattern is captured by the slogan 'this time is different' highlighted by Reinhart and Rogoff (2009). 
Table 2: Budget balance error in official forecast as \% of GDP, in 33 countries: (a) effect of GDP gap; (b) effect of absolute GDP gap

\begin{tabular}{lccc}
\hline Variables & $(1)$ & $(2)$ & $(3)$ \\
& One year ahead & Two years ahead & Three years ahead \\
\hline (a) & & & $0.289^{* * *}$ \\
GDPa & $0.093^{* * *}$ & $0.258^{* * *}$ & $(0.063)$ \\
Constant & $(0.019)$ & $(0.040)$ & $1.364^{* * *}$ \\
& 0.201 & $0.649 * *$ & $(0.348)$ \\
Observations & $(0.197)$ & $(0.231)$ & 179 \\
$R^{2}$ & 398 & 300 & 0.092 \\
RMSE & 0.033 & 0.113 & 3.095 \\
& 2.248 & 2.732 & $0.325^{* * *}$ \\
(b) & & & $(0.113)$ \\
Absolute GDP & & & $0.780^{* *}$ \\
Constant & 0.056 & $0.245^{* * *}$ & $(0.319)$ \\
Observations & $(0.069)$ & $(0.064)$ & 179 \\
$R^{2}$ & 0.069 & 0.180 & 0.066 \\
RMSE & $(0.157)$ & $(0.237)$ & 3.139 \\
\hline
\end{tabular}

${ }^{a}$ GDP is measured as deviation from a quadratic trend, and lagged so that it lines up with the year in which the forecast was made.

${ }^{\mathrm{b}}$ Absolute GDP is the absolute value of the GDP deviation.

${ }^{*} p<0.1,{ }^{* *} p<0.05,{ }^{* *} p<0.01$. Robust standard errors in parentheses, clustered by country.

report the results of regressions to explain official errors in forecasting the GDP growth rate, for a sample of 33 countries. ${ }^{18}$ Tables $2 \mathrm{a}$ and $\mathrm{b}$ report analogous results to explain official errors in forecasting the budget surplus. The constant term is always highly significant, confirming that forecasts are overly optimistic on average.

(3) The bias may be present at both ends of the business cycle. In Tables 1a and $2 a$ the coefficient on GDP at the time of the forecast (relative to a long-term quadratic trend) is always highly significant, showing that over-optimism is greater at the height of the business cycle. The unconditional and conditional biases both increase substantially as one moves from the one-year horizon to the three-year horizon. In Tables $1 b$ and $2 b$ the coefficient on the absolute value of the GDP gap is also highly significant (at the two- and three-year horizons), indicating that the bias may be associated with

\footnotetext{
${ }^{18}$ The data are drawn from 1985 to 2009 , although some of the 33 countries are missing data for the early years. Most countries do not make available a time series of official budget forecasts. For details see Frankel (2011), particularly the Data Appendix. Estimation results with fixed effects are available in a subsequent paper.
} 
Table 3: Budget balance error in official forecast as \% of GDP - effect of SGP rules, in 33 countries

\begin{tabular}{lccc}
\hline Variables & $(1)$ & $(2)$ & $(3)$ \\
& One year ahead & Two years ahead & Three years ahead \\
\hline SGP dummy & 0.407 & 0.276 & 0.0219 \\
& $(0.355)$ & $(0.438)$ & $(0.515)$ \\
SGP $\times$ GDP $^{\mathrm{b}}$ & $0.189^{* *}$ & $0.497^{* * *}$ & $0.551^{* * *}$ \\
& $(0.083)$ & $(0.107)$ & $(0.132)$ \\
Constant & 0.033 & $0.466^{*}$ & $\left(0.214^{* * *}\right.$ \\
& $(0.229)$ & $(0.249)$ & 179 \\
Observations & 398 & 300 & 0.076 \\
$R^{2}$ & 0.030 & 0.080 & 3.132 \\
RMSE & 2.254 & 2.788 &
\end{tabular}

${ }^{a}$ SGP is a dummy for countries that are members of the euro and thus subject to the budget rules of the Stability and Growth Pact.

${ }^{\mathrm{b}} \mathrm{GDP}$ is measured as deviation from a quadratic trend and lagged so as to line up with the year in which the forecast was made.

${ }^{*} p<0.1,{ }^{*} p<0.05,{ }^{* *} p<0.01$. Robust standard errors in parentheses.

periods of unusually low GDP as well as unusually high GDP. A plausible interpretation is that genuine uncertainty is high both at the top of the business cycle and at the bottom, so that there is more scope for wishful thinking.

(4) The bias is greater among those European governments that are politically subject to the budget rules in the SGP because they have joined the euro. Authors have found a statistically significant optimism bias for some particular euro members: France, Italy and Portugal over the period 1991-2002 (Hallerberg et al., 2009), and Germany, Italy, Greece, Luxembourg, and Portugal when the data set is updated to 2004 (Von Hagen et al., 2009). Brück and Stephan (2006) explicitly conclude that Eurozone governments have manipulated deficit forecasts before elections since the introduction of the SGP. Similarly, Beetsma et al. (2009) find that ex post budget balances among SGP countries systematically fall short of official ex ante plans. Marinheiro (2010) adds another complete business cycle to the data under the SGP, and again finds that the forecasts of European fiscal authorities are overly optimistic on average. This evidence is not consistently strong across the set of 15 EU countries, but the bias is again high for the euro countries France, Italy, and Portugal at all forecast horizons.

We return to our data set of 33 countries and add a dummy for members of the SGP. Table 3 seeks to explain errors in official forecasts of the growth rate and Table 4 seeks to explain errors in official forecasts of the budget deficit. Countries that are nominally under the budget rules of the SGP are 
J Frankel

Table 4: GDP growth rate error in official forecast - effect of SGP rules, in 33 countries

\begin{tabular}{lccc}
\hline Variables & One year ahead & Two years ahead & Three years ahead \\
\hline SGP dummy & & & \\
& 0.179 & -0.028 & $-1.189^{*}$ \\
SGP $\times$ GDP $^{\mathrm{b}}$ & $(0.222)$ & $(0.374)$ & $(0.674)$ \\
& $0.136^{*}$ & $0.467^{* * *}$ & $0.477^{* * *}$ \\
Constant & $(0.067)$ & $(0.125)$ & $(0.133)$ \\
& 0.239 & $0.876^{* * *}$ & $2.207^{* * *}$ \\
Observations & $(0.168)$ & $(0.251)$ & $(0.625)$ \\
$R^{2}$ & 368 & 282 & 175 \\
RMSE & 0.011 & 0.043 & 0.040 \\
\hline
\end{tabular}

${ }^{a}$ SGP is a dummy for countries that are members of the euro and thus subject to the budget rules of the Stability and Growth Pact.

${ }^{b}$ GDP is measured as deviation from a quadratic trend and lagged so as to line up with the year in which the forecast was made.

${ }^{*} p<0.1,{ }^{* *} p<0.05,{ }^{* *} p<0.01$. Robust standard errors in parentheses.

prone to more upward bias in their forecasts than other countries, the bias is concentrated in boom years, and the bias is again worse at the longer-term horizons than at the one-year horizon. ${ }^{19}$

Thus official forecasts, if not insulated from politics, tend to be overly optimistic in booms, and the problem can be worse when the government is formally subject to a budget rule. Chile's structural budget institutions offer a possible solution to this problem. Since 2000, fiscal policy in Chile has been governed by a structural budget rule that has succeeded in implementing countercyclical fiscal policy. This accomplishment is all the more noteworthy in that Latin American countries dependent on commodity exports have historically experienced fiscal policies that were highly procyclical. During the 2003-2008 boom, the result was a substantial increase in national savings, some of it dedicated to funding of pension-related liabilities of the government. The key innovation is that the responsibility for estimating the extent to which contemporaneous copper prices and GDP have departed from their long-run averages is given to panels of independent experts and thus insulated from the political process.

Further findings:

(5) In most countries, the real growth rate is the key macroeconomic input for budget forecasting. Table 5 shows, for a sample of 33 countries, the highly

${ }^{19}$ The SGP dummy when entered without the GDP interactive term is usually positive and often significant, especially when estimated with fixed effects (reported in first three columns of the two tables in the working paper). 
J Frankel

424

Table 5: GDP growth as a short-term determinant of budget balance in 33 countries

\begin{tabular}{lccc}
\hline Variables & $(1)$ & $(2)$ & $(3)$ \\
& One year ahead & Two years ahead & Three years ahead \\
\hline GDP error & $0.490^{* * *}$ & $0.512^{* * *}$ & $0.455^{* * *}$ \\
& $(0.053)$ & $(0.069)$ & $(0.079)$ \\
Constant & 0.102 & 0.271 & $0.724^{* *}$ \\
& $(0.172)$ & $(0.247)$ & $(0.346)$ \\
Observations & 367 & 277 & 175 \\
$R^{2}$ & 0.280 & 0.369 & 0.322 \\
RMSE & 1.897 & 2.365 & 2.690 \\
\hline
\end{tabular}

Dependent variable is budget surplus as a share of GDP, expressed relative to earlier forecast. Independent variable is GDP expressed relative to earlier forecast at same horizon. Details in Frankel (2011).

Table 6: Short-term determinants of Chile's budget deficit

Regression of budget balance (ex post budget relative to forecast) against macroeconomic variables (ex post relative to forecast). 1990-2009 (20 observations)

\begin{tabular}{|c|c|c|}
\hline Variables & \multicolumn{2}{|c|}{ Coefficient estimates } \\
\hline Copper price movement ${ }^{a}$ & $\begin{array}{l}0.060 * * \\
(0.021)\end{array}$ & $\begin{array}{c}0.056^{* *} \\
(0.021)\end{array}$ \\
\hline GDP movement & $\begin{array}{c}0.239 \\
(0.187)\end{array}$ & \\
\hline Constant & $\begin{array}{c}0.023 \\
(0.754)\end{array}$ & $\begin{array}{c}0.163 \\
(0.683)\end{array}$ \\
\hline$R^{2}$ & 0.299 & 0.251 \\
\hline RMSE & 2.655 & 2.666 \\
\hline
\end{tabular}

\footnotetext{
${ }^{a}$ The copper price movement is here measured as [log(average of end of month price, Jan.- Dec., of the next year) $-\log$ (August 15 -month forward price) $] \times 100$.

${ }^{*} p<0.1,{ }^{* *} p<0.05,{ }^{* *} p<0.01$. Robust standard errors in parentheses.
}

significant relationship between growth and the budget surplus. For every 1 per cent of growth, relative to what was forecast previously, the budget improves by about half that amount, relative to what was forecast previously.

(6) In Chile the price of copper is the most important single macroeconomic input for forecasting the budget. Table 6 reports for Chile the regression of shortterm determination of the budget, analogous to the preceding table, but with the addition of the copper price. (Again both variables are expressed relative to the attempt to forecast them earlier.) The copper price dominates GDP in budget forecasting. Figure 5 illustrates the relationship graphically. 
J Frankel

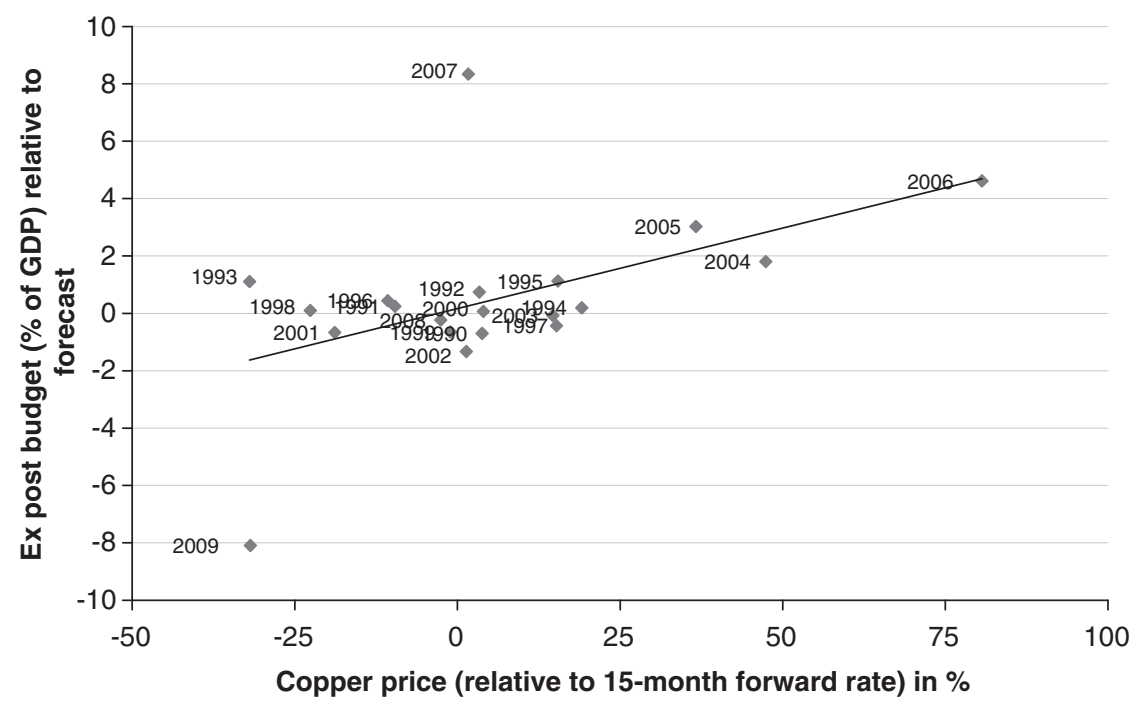

Figure 5: Short-term influence of copper price movements on Chile's budget

(7) Real copper prices on average revert gradually back to a long-run trend. This is not always readily perceived, however. For one thing, 30 years of experience is not enough to discern the pattern; one needs a century or two of data. For another thing, forecasts are more uncertain in booms, as judged by optionimplied volatility. Thus it is easy to see how government officials could mistakenly extrapolate commodity price upswings and, in light of the preceding finding, how this would in turn lead to overly optimistic budget forecasts.

(8) Unlike in other countries, Chile's official forecasts are not overly optimistic on average. Figure 6 plots budget forecast errors across countries and across time. The horizontal axis is the output gap at the time of the forecast. Other countries frequently overestimate their budget surplus, especially when output is high. (A majority of the dots lie above the horizontal line that represents zero error in forecasting the budget, especially toward the right.). But Chile rarely does so. (Most of the 'X's fall below the horizontal line.) Chile's fiscal institutions have apparently enabled it to avoid the problem of official forecasts that unrealistically extrapolate in boom times.

Chile's fiscal institutions could usefully be emulated everywhere, most obviously in other commodity-exporting countries, but in industrialized countries as well. ${ }^{20}$

${ }^{20}$ Frankel (2011) explains and analyzes Chile’s structural budget institutions in more detail, and gives further references. 
426

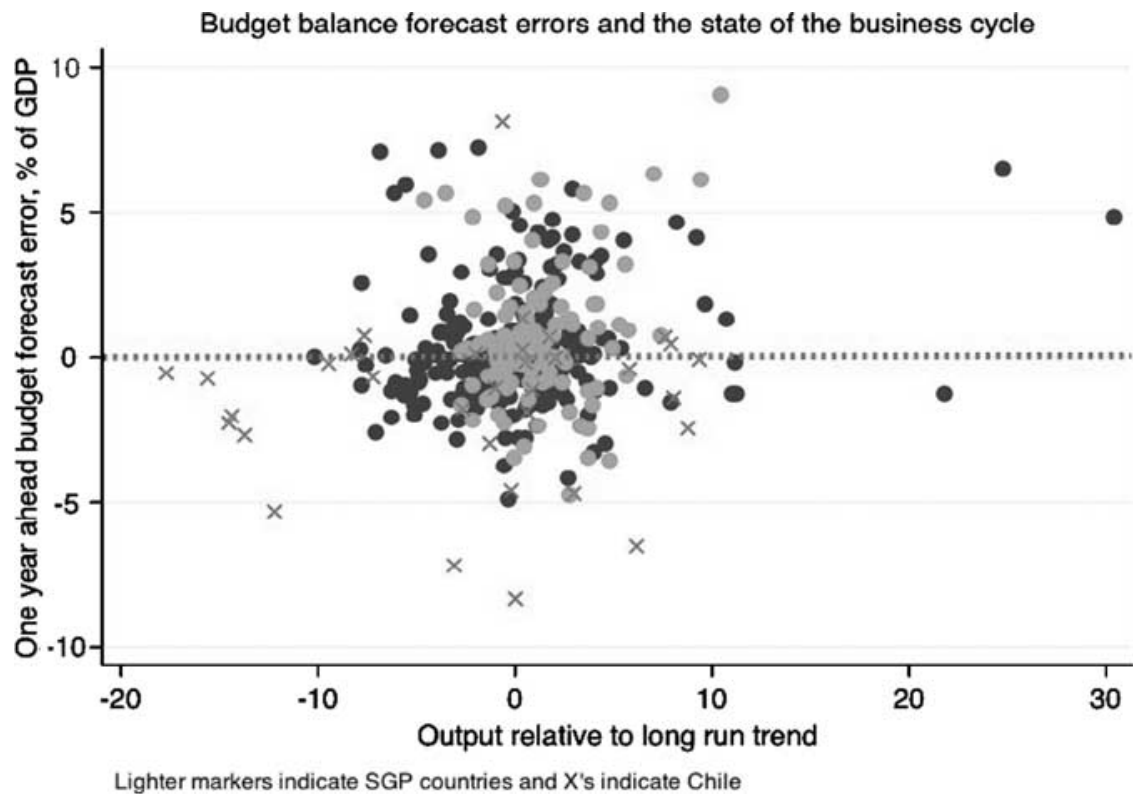

Figure 6: Chile's official budget forecasts are not prone to the optimism bias of other countries annual data, 1985-2010, 33 countries. Data sources and other details in Frankel (2011)

\section{COUNTERCYCLICAL FISCAL INSTITUTIONS GENERALIZED FOR OTHER COUNTRIES}

Any country could usefully apply variants of the Chilean fiscal device, not just producers of minerals. Even large diversified industrialized countries could set up independent institutions charged by law with estimating the output gap and such other budget-relevant macroeconomic variables as the inflation rate and the fractions of GDP going to wage versus non-wage income. In some countries, a useful reinforcement of the Chilean idea would be to formalize the details of the procedure into law and give the panels legal independence. There could be laws protecting them from being fired, as there are for governors of independent central banks. The principle of a separation of decisionmaking powers should be retained: the rules as interpreted by the panels determine the total amount of spending or budget deficits, while the elected political leaders determine how that total is allocated.

There remain two technical questions: how much of the structural budget calculations are to be delegated to the independent panels of experts, and whether the budget rules are interpreted as ex ante or ex post. The procedures that compute the structural balance in Chile involve a number of calculations 
that are in fact made inside the Ministry of Finance, rather than by the panels of experts. One could imagine moving the locus of these calculations from the Ministry to the independent panels. This might require a standing bureaucracy, in the manner of the US Congressional Budget Office. If the independent agency were given more comprehensive control over fiscal policy, it would then approach symmetry with the delegation of monetary policy to independent central banks. ${ }^{21}$ But few reformers suggest that the details of tax and spending policy could or should be delegated to an agency that is not directly accountable in a democratic way.

The second, related, question is whether the targeting is to be ex ante or ex post. An ex post rule for the budget deficits would have to be phrased as a target range, or as an upper bound, because unanticipated economic developments make it impossible for anyone to hit a budget target precisely. The alternative is for the rule to be interpreted as ex ante: tax rates, spending parameters and so forth are set so as to produce the desired target if all goes precisely as expected, while recognizing that there will be unanticipated deviations during the course of the year.

The analogous issue is familiar in the context of monetary policy. If the target variable is the money supply or inflation rate, the authorities cannot be expected to hit it exactly, as opposed to the regime when the target is the price of gold or the exchange rate. The usual approach is that the monetary authorities announce a target range for $\mathrm{M} 1$ or the inflation rate. Conceptually, a sincere central bank will set the range so that it can achieve an outcome within the specified range, say $95 \%$ of the time. The public can then monitor the ability of the central bank to deliver on its commitment. An alternative proposal is that the monetary authorities set the parameters so as to hit a desired ex ante inflation target. If the one true model of how the economy operates were known to the central bank, which in turn announced it to the public, the two procedures would be equivalent. In reality however, the model is highly uncertain, everyone knows that it is uncertain, and different elements among the staff and different members of the monetary policy committee vary as to their preferred models. Thus it is less practical to announce an ex ante target. The members of the monetary policy committee would have to negotiate with each other an ever-changing common model and set of forecasts, a cumbersome way to go about negotiating a decision on monetary policy.

In the case of the fiscal expert panels, however, setting an ex ante target may be more feasible. More precisely, the panel could be charged with

${ }^{21}$ Wyplosz (2005) and Jonung and Larch (2006) have proposed setting up an independent Fiscal Policy Committee that would reproduce what independent Monetary Policy Committees do. Others noting the analogy with monetary policy include Alesina and Perotti (1996). 
evaluating whether the government's budget proposal would hit the desired budget target, not only if output were at potential and the copper price were at its long-run equilibrium, which they already have to do in Chile, but also, more comprehensively, if growth and other economic outcomes were at their expected levels.

\section{Acknowledgements}

An earlier version of this paper appears as Harvard Kennedy School RWP11-014, February 2011. The author would like to thank Jesse Schreger for research assistance, the Weatherhead Center for International Affairs at Harvard for support, participants at the NYU conference for comments, and Paul Wachtel for editorial suggestions.

\section{REFERENCES}

Alesina, A, Campante, F and Tabellini, G. 2008: Why is fiscal policy often procyclical? Journal of the European Economic Association 6(5): 1006-1036.

Alesina, A and Perotti, R. 1996: Fiscal discipline and the budget process. American Economic Review 86(2); Papers and Proceedings (May), 401-407.

Ashiya, M. 2007: Forecast accuracy of the Japanese government: Its year-ahead GDP forecast is too optimistic. Japan and the World Economy 19(1): 68-85.

Auerbach, A. 1994: The U.S. fiscal problem: Where we are, how we got here and where we're going. In: NBER Macroeconomics Annual 1994, Volume 9, pp. 141-186. NBER WP No. 4709.

Auerbach, A. 1999: On the performance and use of government revenue forecasts. National Tax Journal 52(4): 765-782.

Beetsma, R, Giuliodori, M and Wierts, P. 2009: Planning to cheat: EU fiscal policy in real time. Economic Policy 24(60): 753-804.

Brück, T and Stephan, A. 2006: Do Eurozone countries cheat with their budget deficit forecasts? Kyklos 59(1): 3-15.

Calderón, C and Schmidt-Hebbel, K. 2003: Macroeconomic policies and performance in Latin America. Journal of International Money and Finance 22(7): 895-923.

Feldstein, M. 1994: American economic policy in the 1980s: A personal view. American economic policy in the 1980s. University of Chicago Press: Chicago pp. 1-79.

Fernald, L, Gertler, P and Neufeld, L. 2008: Role of cash in conditional cash transfer programmes for child health, growth, and development: An analysis of Mexico's Oportunidades. Lancet 371 (March 8): 828-837.

Fingleton, E. 1995: Blindside: Why Japan is still on track to overtake the U.S. by the year 2000. Houghton Mifflin: Boston, MA.

Forni, L and Momigliano, S. 2004: Cyclical sensitivity of fiscal policies based on real-time data. Economic Research Department, Temi di discussione (Economic working papers) no. 540, Bank of Italy.

Frankel, J. 1993: The evolving Japanese financial system, and the cost of capital. In: Walter, I and Hiraki, T (eds). Restructuring Japan's financial markets. Irwin Press and New York University: New York. pp. 235-285.

Frankel, J. 2001: Economic Advantages of America. Europa und USA im Spannungsfled von Wirtschaft und Politik, Schloss Schönbrunn, Vienna, 16 May, http://www.hks.harvard.edu/fs/ jfrankel/ViennaUSrev523.pdf. 
Frankel, J. 2003: Republican and democratic presidents have switched economic policies. Milken Institute Review 5(1): 18-25.

Frankel, J. 2008: Snake-oil tax cuts. Briefing Paper 221, Economic Policy Institute.

Frankel, J. 2010a: Mauritius: African success story. In: Edwards, S, Johnson, S and Weil, D (eds). African Successes. forthcoming.

Frankel, J. 2011: A solution to fiscal procyclicality: The structural budget institutions pioneered by Chile. forthcoming in Fiscal Policy and Macroeconomic Performance, edited by Luis Felipe Céspedes, Jordi Galí, and Yan Carrière-Swallow, Series on Central Banking, Analysis, and Economic Policies, November. Central Bank of Chile WP No. 604 or Harvard Center for International Development WP 216, January 2011. 14th Annual Conference of the Central Bank of Chile, 21-22 October 2010, Santiago.

Frendreis, J and Tatalovich, R. 2000: Accuracy and bias in macroeconomic forecasting by the administration, the CBO, and the Federal Reserve Board. Polity 32(4): 623-632.

Gale, W and Kelly, B. 2004: The 'no new taxes' pledge. Tax Notes 12(July): 197-209.

Gale, W and Orszag, P. 2004: Bush administration tax policy: Revenue and budget effects. Tax Analysts 4(October): 105-118.

Gavin, M and Perotti, R. 1997: Fiscal policy in Latin America. NBER Macroeconomics Annual 12: 11-61.

Goolsbee, A. 1999: Evidence on the high-income Laffer curve from six decades of tax reform. Brookings Papers on Economic Activity, no. 2, p. 24.

Hallerberg, M, Strauch, R and von Hagen, J. 2009: How forms of fiscal governance affect fiscal performance. In: Hallerberg, M, Strauch R and Hagen Jv (eds). Fiscal Governance in Europe. Cambridge University Press: Cambridge. Revised version of Von Hagen, Hallerberg, and Strauch. 2004: Budgetary forecasts in Europe - The track record of stability and convergence programmes. ECB WP No. 30.

Heijman, WJM and van Ophem, JAC. 2005: Willingness to pay tax: The curve revisited for 12 OECD countries. The Journal of Socio-Economics 34(5): 714-723.

Henríquez, JO. 2006: The Mexican system of electoral conflict resolution in comparative perspective. Taiwan Journal of Democracy 2(1): 51-60.

Ilzetski, E and Vegh, C. 2008: Procyclical fiscal policy in developing countries: Truth or fiction? NBER WP no. 14191.

Johnson, C. 1982: MITI and the Japanese miracle. Stanford University Press: Stanford, CA.

Johnson, S. 2009: The quiet coup. The Atlantic May.

Jonung, L and Larch, M. 2006: Improving fiscal policy in the EU: The case for independent forecasts. Economic Policy 21(47): 491-534.

Kaminsky, G, Reinhart, C and Vegh, C. 2005: When it rains, it pours: Procyclical capital flows and macroeconomic policies. NBER Macroeconomics Annual 2004 19: 11-82.

Marinheiro, C. 2010: Fiscal sustainability and the accuracy of macroeconomic forecasts: Do supranational forecasts rather than government forecasts make a difference? GEMF Working Papers 2010-07, Faculdade de Economia, Universidade de Coimbra, forthcoming, International Journal of Sustainable Economy.

McNab, RM, Rider, M and Wall, K. 2007: Are errors in official US budget receipts forecasts just noise? Andrew Young School Research Paper Series Working Paper 07-22, April.

McNees, S. 1995: An assessment of the 'official' economic forecasts. New England Economic Review July: 13-23.

Medas, P and Zakharova, D. 2009: Primer on fiscal analysis in oil-producing countries. IMF Working Paper 56, March.

Mendoza, EG and Oviedo, PM. 2006: Fiscal policy and macroeconomic uncertainty in developing countries: The tale of the tormented insurer. NBER Working Paper No. 12586, October.

Neut, A and Velasco, A. 2003: Tough policies, incredible policies? NBER Working Paper No. 9932, September. 
Niskanen, W. 2002: Comment. In: Frankel, J and Orszag, P (eds). American Economic Policy in the 1990s. MIT Press: Cambridge pp. 184-187.

Niskanen, W. 2004: Starve the beast does not work. Cato Policy Report 26(2): 2.

Niskanen, W. 2006: Limiting government: The failure of 'starve the beast'. Cato Journal 26(3): 553-558.

Perry, G. 2003: Can fiscal rules help reduce macroeconomic volatility in the Latin America and Caribbean region? World Bank Policy Research Working Paper No. 3080.

Rajan, R. 2005: Has financial development made the world riskier? Federal Reserve Bank of Kansas City: 313-369.

Rawlings, L and Rubio, G. 2005: Evaluating the impact of conditional cash transfer programs. World Bank Research Observer 20(1): 29-55.

Reinhart, C and Rogoff, K. 2009: This Time is Different: Eight Centuries of Financial Folly. Princeton University Press: Princeton, NJ.

Romer, C and Romer, D. 2007: Do tax cuts starve the beast: The effect of tax changes on government spending. NBER WP no. 13548.

Stockman, D. 1986: The triumph of politics: Why the Reagan revolution failed. Harper and Row: New York.

Talvi, E and Vegh, C. 2005: Tax base variability and procyclicality of fiscal policy. Journal of Development Economics 78(1): 156-190.

Tornell, A and Lane, P. 1999: The voracity effect. American Economic Review 89(1): 22-46.

Trabandt, M and Uhlig, H. 2010: How far are we from the slippery slope? The Laffer curve revisited. ECB Working Paper 1174, 2010. NBER WP No. 15343, 2009. CEPR DP No. 5657, 2006.

Vogel, E. 1979: Japan as number one: Lessons for America. Harvard University Press: Cambridge, MA.

Wyplosz, C. 2005: Fiscal policy: Institutions versus rules. National Institute Economic Review. Also CEPR Discussion Papers no. 3238. 